\title{
Effects of supplementary treatment with bovine growth hormone on hormonal and ovulatory responses to inhibin immunization in ewes
}

\author{
D. S. Tannetta, M. D. Fray, J. H. M. Wrathall, E. C. L. Bleach, \\ R. G. Glencross and P. G. Knight* \\ School of Animal and Microbial Sciences, The University of Reading, Whiteknights, \\ Reading RG6 6AJ, UK
}

\begin{abstract}
The aim of this study was to determine whether supplementary treatment with recombinant bovine growth hormone(rbGH) can enhance the ovulatory response of ewes to inhibin immunization. Crossbred ewes $(n=20)$ were actively immunized against bovine inhibin a1-29 peptide conjugate while 20 ewes served as controls. Oestrus was synchronized using progestagen sponges and ewes were allocated to four groups: control ewes $(n=10)$; control ewes given $\mathrm{rbGH}(n=10)$; inhibin-immunized ewes $(n=10)$ and inhibin-immunized ewes given $\mathrm{rbGH}(n=10)$. A single s.c. dose of $\mathrm{rbGH}(50 \mathrm{mg})$ was given 7 days before sponge removal. Blood was collected for measurement of inhibin antibody titre, and concentrations of insulin-like growth factor I (IGF-I), FSH, oestradiol and progesterone. Ovulation, pregnancy and lambing rates were also recorded. All inhibin-immunized ewes produced antibodies that bound ${ }^{125}$ I-labelled $(32 \mathrm{kDa})$ inhibin. The concentration of FSH in the plasma of the ewes after the second booster inhibin immunization was higher than that in control ewes $(P<0.005)$. Treatment with rbGH promoted a $2-3$-fold increase in plasma concentration of IGF-I $(P<0.001)$; the response was less $(P<0.01)$ in immunized compared with control ewes. Treatment with $\mathrm{rbGH}$ alone had no significant effect on the concentration of FSH or oestradiol or on ovulation rate or litter size. Overall, inhibin-immunized ewes had higher mean FSH concentrations $(P<0.002)$, higher preovulatory oestradiol surges $(P<0.05)$ and higher progesterone concentrations in the luteal phase $(P<0.0001)$. Treatment with $\mathrm{rbGH}$ reduced the effects of immunization on FSH $(P<0.01)$ and progesterone $(P<0.02)$ concentrations. Immunized ewes showed a threefold increase in ovulation rate $(P<0.001)$ and a 1.8 -fold increase in litter size $(P<0.05)$ compared with control ewes. In immunized ewes given rbGH, ovulation rate was increased by a factor of 2.2 and litter size by a factor of 1.8. In conclusion, these data do not support the hypothesis that supplementary treatment of ewes with rbGH to raise plasma IGF-I concentrations (and presumably intraovarian IGF-I) can enhance the ovulatory response to inhibin immunization.
\end{abstract}

\section{Introduction}

Experiments in prepubertal gilts (Spicer et al., 1992), adult cattle (Gong et al., 1991; Herrler et al., 1994) and ewes (Gong et al., 1996a) have shown that administration of recombinant $\mathrm{GH}$ raises the concentration of insulin-like growth factor (IGF-I) in the serum and is associated with an increase in the number of small antral follicles on the ovary. Treatment with GH has also been shown to raise the concentration of IGF-I in the ovary (Davoren and Hsueh, 1986; Bryan ef al., 1989; Spicer et al., 1992; Herrler et al., 1994; Samaras et al., 1994) and to increase the production of IGF-I by isolated follicles in vitro (Gong et al., 1996a). This indicates that systemically administered GH can affect ovarian follicular development either by increasing

*Correspondence.

Received 9 October 1997. circulating IGFs or by acting locally to enhance intrafollicular production of IGFs by theca or granulosa cells. Studies in several species including sheep have shown that insulin and IGFs can directly affect the proliferation and steroidogenic capacity of cultured granulosa cells (Savion et al., 1981; Baranao and Hammond, 1984; Monniaux and Pisselet, 1992; Spicer et al., 1993a), thecal (Hernandez et al., 1988; Morley et al., 1989; Stewart et al., 1995) and luteal (Sauerwein et al., 1992; Parmer et al., 1991) cells.

The synthesis and secretion of IGFs by the liver and other tissues is positively regulated by GH while the actions of IGFs on target cells are modulated by IGF-binding proteins (IGF$\mathrm{BPs}$ ) of which six have been cloned and sequenced to date (reviewed by Lamson et al., 1991). IGF-BPs, mainly of hepatic origin, are present in the peripheral circulation but they are also produced locally by various cell types including ovarian granulosa, thecal and luteal cells (reviewed by Giudice, 1992; 
Spicer and Echternkamp, 1995). At the ovary, it has been proposed that locally produced IGFs have an important role in the follicle selection process by sensitizing follicles to gonadotrophins (Baranao and Hammond, 1984; Adashi et al., 1985). Such an action could permit certain follicles to continue development and maintain their steroidogenic capacity even though prevailing gonadotrophin concentrations are insufficient to support the growth of other follicles.

Evidence in vitro that IGF-I can synergize with FSH to enhance its trophic actions on granulosa cells (Adashi ef al., 1985) is supported by more recent data in vivo showing that systemic administration of $\mathrm{GH}$ can also improve the superovulatory response to exogenous gonadotrophin in cattle (Gong et al., 1993, 1996b; Herrler et al., 1994), gilts (Matamoros et al., 1991) and women (Matson et al., 1989; Homburg et al., 1990). Moreover, these findings suggest that other treatments that increase plasma FSH concentrations might also generate an additive ovarian response when combined with $\mathrm{GH}$ administration.

Active immunization of sheep against inhibin increases the number of large preovulatory follicles and consistently raises the ovulation rate (O'Shea et al., 1984; Al-Obaidi et al., 1987; Forage et al., 1987; Mizumachi et al., 1990; Wrathall et al., 1990, 1992). The ovarian response to inhibin immunization is generally thought to be mediated by an increase in the concentration of plasma FSH which has been demonstrated in some (AlObaidi et al., 1987; Mizumachi et al., 1990; Wrathall et al., 1990, 1992) but not all (Henderson et al., 1984; Schanbacher, 1988; Fray et al., 1994) studies. It has been suggested that the increased number of healthy ovulatory follicles observed in inhibin-immunized ewes may reflect a decreased rate of atresia rather than an increase in the number of follicles recruited from the primordial pool (McLeod et al., 1992). In contrast, Gong et al. (1993) suggested that the increased number of small antral follicles observed after treatment of cattle with $\mathrm{GH}$ is a consequence of enhanced recruitment of small follicles. Therefore, it is possible that by combining inhibin immunization with $\mathrm{GH}$ administration, these treatments would interact to enhance follicular development further and to promote a greater increase in ovulation rate than that observed in response to inhibin immunization alone. The aim of the present study was to test this hypothesis in ewes, with a view to achieving an improved response in terms of reproductive performance.

\section{Materials and Methods}

\section{Animals and treatments}

Forty adult cross-bred (Blue-faced Leicester $\times$ Swaledale) ewes were used in this experiment. Ewes were kept at pasture with free access to water at all times. In late July, the ewes were divided into three groups: inhibin-immunized ewes $(n=20)$, control ewes immunized with carrier protein $(n=10)$ and non-immunized controls $(n=10)$. The inhibin immunogen used was a synthetic peptide corresponding to the amino-terminal region (1-29) of the mature $\alpha \mathrm{C}$ subunit of bovine inhibin conjugated to tuberculin purified protein derivative (PPD), as described by Wrathall et al. (1990, 1992). Carrier-proteinimmunized ewes were immunized against PPD alone. Ewes received a primary immunization followed by two booster immunizations at intervals of 6 weeks (Wrathall et al., 1992). Two weeks after the second booster immunization, oestrus was synchronized using progestagen-impregnated intravaginal sponges (Chronogest; Intervet UK Ltd, Cambridge, $\mathrm{UK})$; at this time, control and inhibin-immunized ewes were randomly allocated to receive either treatment with $\mathrm{rbGH}$ (10 immunized +10 control ewes) or vehicle injection (10 immunized +10 control ewes). Note that equal numbers of non-immunized and PPD-immunized ewes were allocated to each control group. Seven days before progestagen sponge removal, rbGH (50 mg Sometribove; Monsanto Europe $\mathrm{SA} / \mathrm{NV}$, Brussels) was administered as a single s.c. depot designed to release the hormone over a period of approximately 10 days. Ewes were weighed at the time of rbGH or vehicle administration and 14 days after sponge removal to monitor the effects of treatment. Three days before progestagen sponge removal, fertile raddled Suffolk rams $(n=4)$ were introduced into the ewes' enclosure. Ewes were inspected daily to monitor oestrus and any returns to oestrus during the following 3 weeks. One week after sponge removal, ewes were fasted overnight in preparation for laparoscopic examination of the ovaries the next day to determine ovulation rate. Near to the time of parturition, ewes were moved to indoor lambing enclosures and the outcome of pregnancy for each ewe was subsequently recorded. Blood samples ( $10 \mathrm{ml}$ ) were collected by jugular venepuncture into heparinized tubes at the time of primary and booster immunizations, every 2 days after sponge insertion, daily from the time of sponge removal for 1 week and then every 2-4 days for the remaining 10 days. Plasma samples were separated and stored at $-20^{\circ} \mathrm{C}$ for the determination of inhibin antibody titres and IGF-I, FSH, oestradiol and progesterone concentrations.

\section{Assessment of inhibin antibody titres}

Plasma samples were tested for their ability to bind ${ }^{125} \mathrm{I}$ labelled bovine inhibin $(32 \mathrm{kDa})$, as described by Wrathall et al. (1990, 1992).

\section{Determination of hormone concentrations}

Plasma concentrations of FSH were assessed using a homologous ovine FSH radioimmunoassay kit provided by NIDDK (Bethesda, MD) as reported by Knight and Castillo (1988). Intra- and interassay coefficients of variation were $3.7 \%$ and $6.8 \%$, respectively, and the detection limit of the assay (expressed as the amount of FSH standard required to inhibit the binding of the iodinated tracer (NIADDK-oFSH-I1) to the antibody (NIADDK-anti-oFSH-I; final dilution 1:64 000) by $20 \%$ ) was $0.5 \mathrm{ng} \mathrm{ml}^{-1}$.

Plasma concentrations of total IGF-I were measured by radioimmunoassay after subjecting samples to an acid-ethanol extraction followed by a cryoprecipitation step to remove IGF-binding proteins (Echternkamp et al., 1990). The IGF-I antiserum used was provided by NIDDK (code UB3 189, used at dilution 1:2000). Recombinant human (rh) IGF-I (Bachem Inc., Torrance, CA) was used as a standard and for preparing ${ }^{125}$ I-labelled tracer which was radioiodinated using the iodogen Downloaded from Bioscientifica.com at 04/26/2023 12:59:48PM 
method. Extracted plasma samples gave dilution curves that were parallel to the rhIGF-I standard and recovery of exogenous IGF-I ( $2 \mathrm{ng} \mathrm{ml}^{-1}$ ) added to plasma samples before extraction was $111.2 \pm 7.0 \%$ ( $n=8$ samples). Intra- and interassay coefficients of variation were $8.5 \%$ and $8.6 \%$, respectively. The limit of detection of the assay (expressed as the amount of the IGF-I standard needed to inhibit the binding of the tracer to the antibody by $20 \%$ ) was $5 \mathrm{ng} \mathrm{ml}^{-1}$.

Concentrations of oestradiol in plasma samples were determined using a commercial human oestradiol radioimmunoassay kit (Serono Diagnostics, Hampshire) which was modified and validated for ovine plasma in this laboratory. Modifications were similar to those reported by Mann et al. (1995) and involved (I) using the oestradiol antiserum at a concentration six times lower than that suggested by the manufacturer, (2) making up oestradiol standards $\left(0.25-64 \mathrm{pg} \mathrm{ml}^{-1}\right)$ in charcoalextracted sheep plasma, and (3) including an ether extraction step. This third modification involved extracting triplicate $0.5 \mathrm{ml}$ aliquots of blanks, standards and unknowns by vortex mixing the aliquots for $30 \mathrm{~s}$ with $3 \mathrm{ml}$ diethyl ether (super purity grade; Romil Ltd. Cambridge, UK). After freezing the aqueous phase by placing the tubes in a dry-ice-ether bath, ether extracts were decanted into clean tubes and evaporated to dryness under a stream of air. The residues were then redissolved in assay diluent before continuing with the radioimmunoassay procedure. Intra-assay and interassay coefficients of variation were $11.2 \%$ and $20.5 \%$, respectively and the detection limit of the assay was $0.25 \mathrm{pg}$ per tube (equivalent to $0.5 \mathrm{pg} \mathrm{ml}^{-1}$ ovine plasma).

Plasma progesterone was determined using the enzymelinked immunoassay developed by Sauer et al. (1986), and modified as described by Glencross et al. (1992) using ovine anti-progesterone serum (S1509/16) and a standard range of progesterone concentrations of $0-32 \mathrm{ng} \mathrm{ml}^{-1}$ in charcoalstripped sheep serum. Intra- and interassay coefficients of variation were $9.8 \%$ and $14.9 \%$, respectively. The limit of detection of the assay was $0.2 \mathrm{ng} \mathrm{ml}^{-1}$.

\section{Statistical analysis}

Within- and between-group comparisons of inhibin antibody titres and plasma FSH concentrations during the initial immunization period were made using Student's paired and unpaired $t$ tests, respectively. Repeated measures two-way analysis of variance (ANOVA) was used to evaluate changes in plasma hormone concentrations over time in the four treatment groups. Between-group comparisons of ovulation rate, lambs born per ewe and lambs born alive per ewe were made using two-way ANOVA. Unless stated otherwise, values presented are means \pm SEM.

\section{Results}

Before rbGH treatment, one non-immunized control ewe sustained a fractured leg and was removed from the study. One of the 20 inhibin-immunized ewes failed to respond to the immunogen (no antibodies were detected in the plasma) and data from this ewe were subsequently excluded.

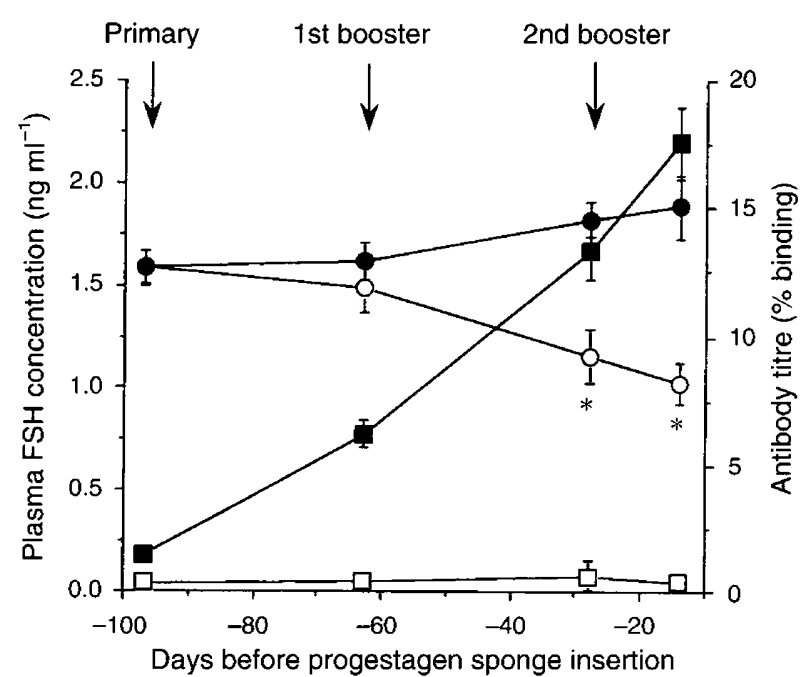

Fig. 1. Plasma concentrations of FSH (circles) and inhibin antibody titres (squares) in control ewes (open symbols; $n=20$ ) and ewes undergoing active immunization against inhibin (closed symbols; $n=20$ ). The inhibin immunogen used was a synthetic peptide corresponding to the $\mathrm{N}$-terminal sequence $\left((1-29) \mathrm{Tyr}^{30}\right)$ of the $\alpha \mathrm{C}$ subunit of bovine inhibin conjugated to tuberculin purified protein derivative (PPD). Ten of the control ewes were immunized against PPD alone, while the other ten were not immunized. Inhibin antibody titres represent the percentage binding of ${ }^{125} \mathrm{I}$-labelled bovine inhibin $(32 \mathrm{kDa})$ to diluted (1:1000) plasma samples. Intravaginal progestagen sponges were inserted 2 weeks after the second booster to effect oestrus synchronization. Values are means $\pm \mathrm{SEM}$. ${ }^{*} P<0.005$ compared with immunized group.

\section{Plasma anti-inhibin titres and FSH during immunization}

All ewes except one (referred to above) showed a gradual increase in inhibin antibody titre following primary immunization against bovine inhibin $\alpha I-29$ peptide-PPD conjugate $(P<0.0001)$. Antibody titres in non-immunized and PPDimmunized control ewes remained at $<2 \%$ binding. Therefore, PPD-immunized and control ewes were combined to give a group of 20 control animals. The mean antibody titre in the inhibin-immunized group at the time of progestagen sponge insertion was $18 \pm 1.4 \%$ compared with $<1 \%$ in the combined control group (Fig. 1). Mean plasma concentrations of FSH were higher $(P<0.005)$ in inhibin-immunized ewes compared with controls at the time of the second booster immunization and 2 weeks thereafter.

\section{Plasma hormones after rbGH treatment in control and inhibin immunized ewes}

Plasma IGF-I. rbGH treatment promoted a sustained 2-3fold increase in the circulating concentration of total IGF-I in both control and inhibin-immunized ewes $(P<0.001$; Fig. 2$)$, and concentrations remained higher than those in the corresponding vehicle-injected groups for at least 15 days. Inhibin immunization had no effect on the concentration or secretory pattern of IGF-I in vehicle-treated ewes but significantly attenuated the IGF-I response to rbGH (two-way ANOVA: $\mathrm{rbGH} \times$ inhibin immunization interaction, $P<0.005)$. In both 
control and inhibin-immunized groups treated with vehicle, plasma concentrations of IGF-I increased after sponge withdrawal to reach maximal values $I$ day after the preovulatory oestradiol surge. PPD-immunized control ewes had circulating

(a)

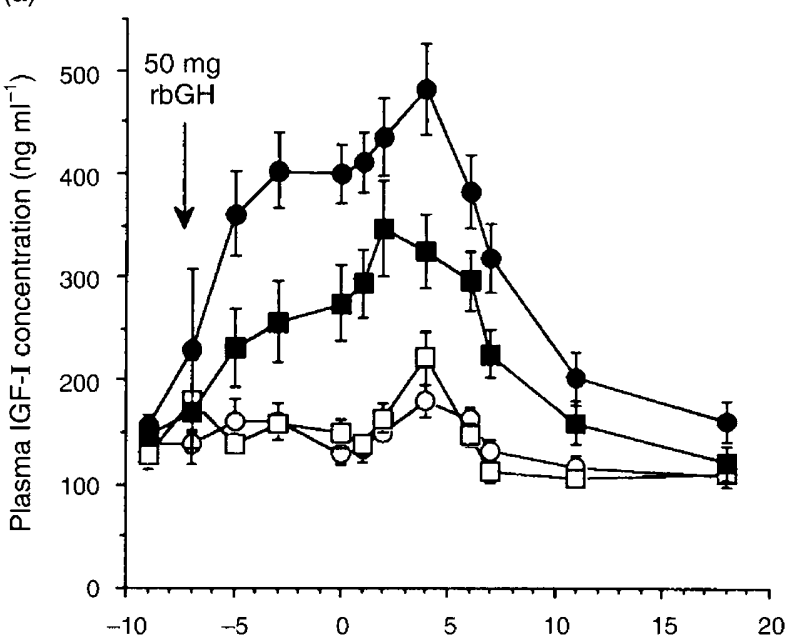

(b)

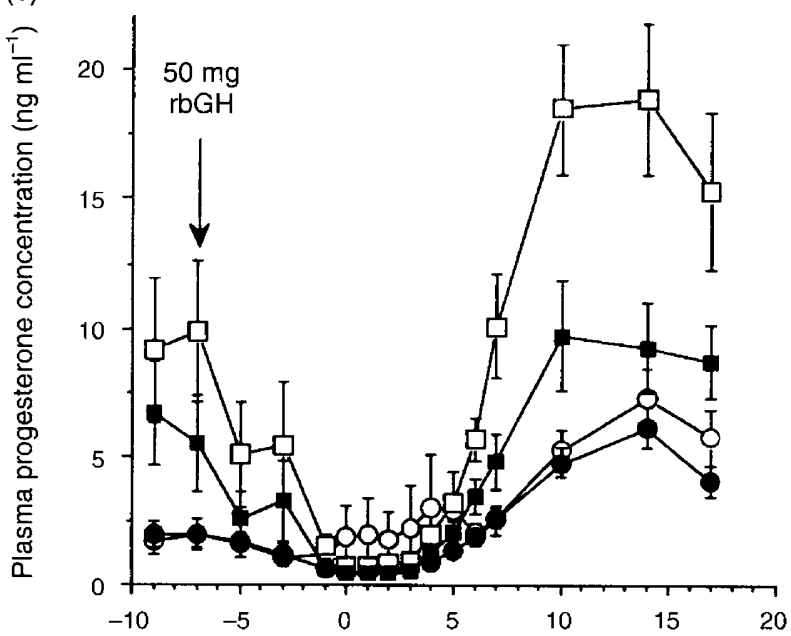

(c)

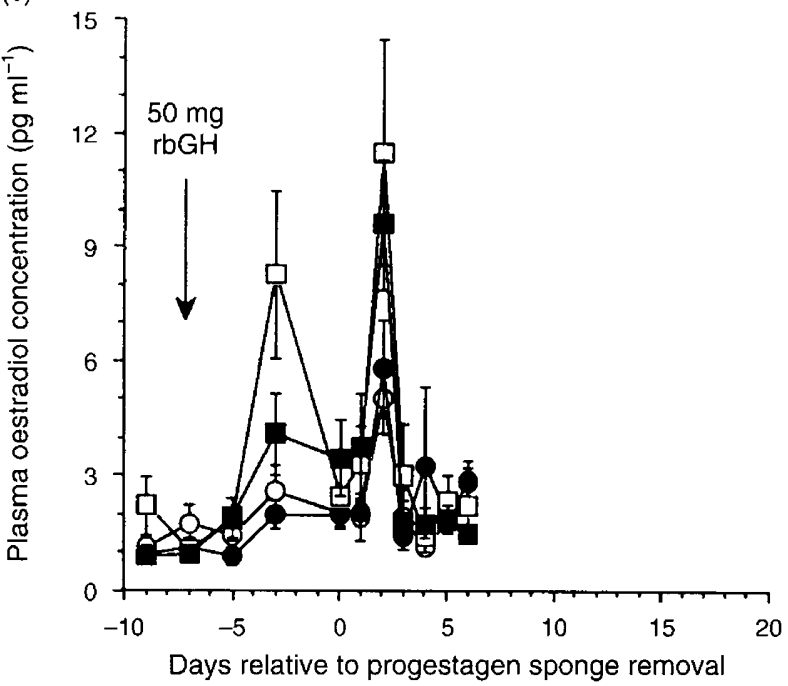

IGF-I concentrations comparable to those of non-immunized controls and responded to the $\mathrm{rbGH}$ injection to the same degree.

Plasma progesterone. Three to four days after sponge removal the expected rise in the plasma concentration of progesterone was observed in all ewes, confirming that ovulation had occurred (Fig. 2b). Peak progesterone concentrations were observed 10-14 days after sponge removal. Repeated measures two-way ANOVA of progesterone profiles for the synchronized luteal phase (i.e. days 5-17 after sponge removal) showed that inhibin immunization alone significantly increased progesterone concentrations $(P<0.0001)$, an effect that was reduced by $\mathrm{rbGH}$ treatment (inhibin immunization $\times \mathrm{rbGH}$ interaction; $P<0.02$ ). In contrast to its effect in immunized ewes, treatment with $\mathrm{rbGH}$ did not significantly attenuate the increase in luteal progesterone in control ewes.

Plasma oestradiol. Both groups of inhibin-immunized ewes (vehicle-treated and rbGH-treated) displayed preovulatory oestradiol surges that were about two times greater than in the corresponding control groups $(P<0.05$; Fig. 2c). Treatment with rbGH did not significantly affect the magnitude of the preovulatory oestradiol peak in either control or inhibinimmunized animals. Both inhibin-immunized groups also had higher mean plasma concentrations of oestradiol than their corresponding control groups 3 days before progestagen sponge withdrawal, presumably reflecting increased follicular activity in these ewes. However, this difference was only significant $(P<0.05)$ in the case of the vehicle-injected groups.

Plasma FSH. Since blood samples were only collected at a maximum frequency of one per day, it was not possible to define clear profiles of plasma FSH in this study (data not shown). Therefore, mean plasma FSH concentrations over the period from rbGH injection until the end of the sampling period (day 17 after sponge withdrawal) were calculated for each ewe to facilitate a statistical comparison between the four treatment groups, and these values were subjected to two-way ANOVA (inhibin immunization and rbGH treatment as main effects). Inhibin immunization significantly increased the overall mean FSH concentration $(P<0.002)$, while rbGH treatment alone had no effect $(P=0.2$; Fig. 3$)$. However, rbGH treatment reduced the effect of inhibin immunization on the plasma concentration of FSH as indicated by a significant $(P<0.05)$ interaction between $\mathrm{rbGH}$ and immunization.

Fig. 2. Effects of inhibin immunization (IMM; immunized ewes, squares; controls, circles) and treatment with recombinant bovine growth hormone $(\mathrm{rbGH}$; rbGH treated, closed symbols; non-treated ewes, open symbols), alone and in combination, on plasma concentrations of (a) insulin-like growth factor (IGF-I) (b) progesterone and (c) oestradiol in ewes during the synchronized oestrous cycle. Values are means $\pm \operatorname{SEM}(n=9$ or 10$)$. Effects of the two treatments and extent of treatment interaction were evaluated by repeated-measures two-way ANOVA and results are given in the text. 


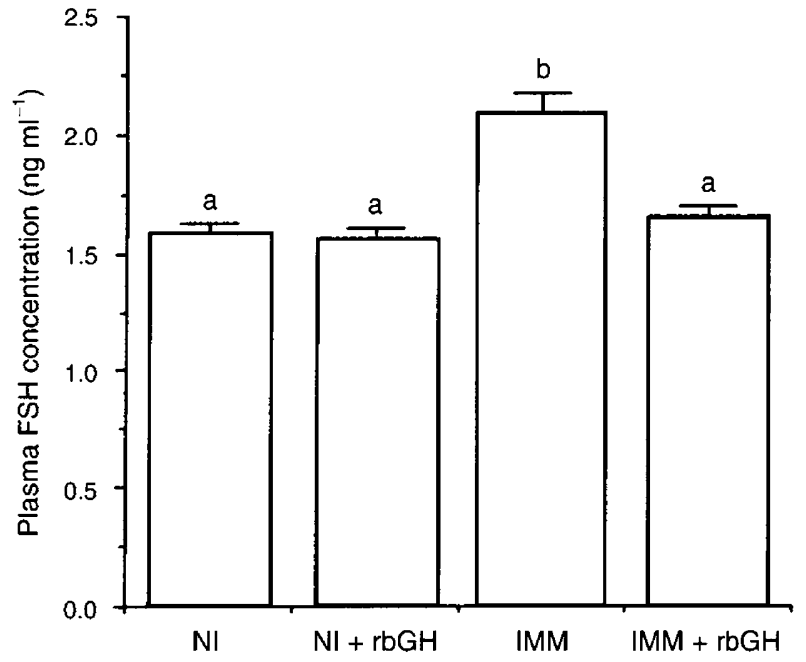

Fig. 3. Effects of inhibin immunization (IMM) and treatment with recombinant bovine growth hormone $(\mathrm{rbGH})$, alone and in combination, on overall mean ( \pm SEM; $n=9$ or 10 ) plasma concentrations of FSH in ewes during the synchronized oestrous cycle. NI indicates the non-immunized control group. Means without a common letter are significantly $(P<0.001)$ different.

\section{Changes in live mass}

There was no significant difference between groups in the mean live mass at the time of $\mathrm{rbGH}$ or vehicle administration (Table 1). Mean live mass increased in all four groups over the following 3 weeks. Respective increases recorded were 5.1\% and $4.2 \%$ for non-immunized and PPD-immunized controls, $8.8 \%$ and $6.3 \%$ for non-immunized and PPD-immunized ewes treated with $\mathrm{rbGH}$, and $1.5 \%$ and $2.6 \%$ for inhibin-immunized ewes treated with vehicle and rbGH.

\section{Ooulation rate}

Inhibin immunization alone increased the mean ovulation rate by a factor of three $(P<0.001$; Table 1$)$, while inhibinimmunized ewes given $\mathrm{rbGH}$ treatment showed a 2.2 -fold increase $(P<0.001$ compared with controls, but not significant compared with inhibin-immunized ewes given vehicle). Treatment with rbGH alone had no effect on ovulation rate. Within the inhibin-immunized groups, there was no significant correlation between inhibin antibody titre and ovulation rate or between peak progesterone concentrations and ovulation rate (data not shown).

\section{Conception, pregnancy and lambing rates}

There was no effect of inhibin immunization or rbGH treatment on conception rate to first service and all ewes had conceived by the second service (Table 1). The duration of pregnancy did not differ between the four treatment groups (data not shown), although two ewes (one from the group immunized with inhibin and injected with vehicle and one from the group immunized with inhibin and treated with $\mathrm{rbGH}$ ) developed pregnancy toxaemia during late pregnancy and so were slaughtered several weeks before their expected lambing dates. The number of lambs carried by these two ewes was recorded and these data were included in the group means for the total number of lambs born per ewe but excluded from the group means for the number of viable lambs per ewe.

Inhibin immunization either alone or in combination with $\mathrm{rbGH}$ treatment was associated with an $81 \%$ increase $(P<0.05)$ in the total number of lambs born per ewe (Table 1). Treatment with $\mathrm{rbGH}$ alone had no effect on the total number of lambs born per ewe. Although both groups of inhibin-immunized ewes produced $65 \%$ more viable lambs per ewe than their respective control groups, individually, these differences were not statistically significant. The increased lamb mortality rate for the immunized ewes was probably due to the reduced birth weight of their lambs, a consequence of increased litter size. Lambs from control ewes weighed on average twice that of lambs from inhibin-immunized ewes $(5.3 \pm 0.2 \mathrm{~kg}$ versus $2.7 \pm 0.2 \mathrm{~kg} ; P<0.001)$.

\section{Discussion}

Consistent with earlier studies in this laboratory (Wrathall $e$ t al., 1990, 1992), immunization of ewes against the bovine inhibin aI-29-PPD conjugate was associated with a small, though significant increase in the circulating concentrations of FSH and a substantial (threefold) increase in the ovulation rate, which resulted in an increased litter size. Administration of $\mathrm{rbGH}$ raised plasma concentrations of IGF-I by two to three times, in agreement with previous reports in several species including sheep (Davis et al., 1990; Spicer et al., 1992; Gong et al., 1991, 1996a; Eckery et al., 1994). When administered to nonimmunized ewes, rbGH had no effect on the circulating concentrations of FSH, oestradiol or progesterone. Likewise, ovulation rate and subsequent litter size were not affected. This lack of effect of $\mathrm{rbGH}$ on the circulating concentration of FSH and ovulation rate is consistent with earlier reports in sheep (Davis et al., 1990; Eckery et al., 1994; Gong et al., 1996a) and cattle (Gong et al., 1991, 1993).

Contrary to our expectations based on recent studies involving cattle receiving superovulatory treatment with gonadotrophin combined with rbGH (Gong et al., 1993, 1996b), administration of rbGH failed to enhance the ovulatory response to inhibin immunization in sheep and did not influence the subsequent lambing rate. In fact, although the difference was not significant, rbGH treatment reduced the mean ovulation rate in immunized ewes by $25 \%$, suggesting that $\mathrm{rbGH}$ had an adverse effect on preovulatory follicle development. A comparison of hormone profiles showed that $\mathrm{rbGH}$ treatment significantly reduced the stimulatory effect of inhibin immunization on the circulating concentration of FSH and on the concentration of progesterone in the luteal phase; a non-significant reduction in the circulating concertration of oestradiol was also noted. The tendency for the mean ovulation rate to be reduced in inhibin-immunized ewes receiving supplementary rbGH may be a consequence of the observed significant reduction in FSH. However, the ovulation rate in immunized ewes treated with rbGH was still more than two times greater than in non-immunized controls, in spite of their very similar FSH concentrations. This observation reinforces previous evidence that the ovulatory response to inhibin 
Table 1. Mean ( \pm SEM) ewe live mass and ovulation, conception and lambing rates for inhibin-immunized and control ewes with and without rbGH treatment

\begin{tabular}{|c|c|c|c|c|c|c|c|}
\hline \multirow{2}{*}{$\begin{array}{l}\text { Treatment } \\
\text { group }\end{array}$} & \multicolumn{2}{|c|}{ Live mass $(\mathrm{kg})$} & \multirow{2}{*}{$\begin{array}{l}\text { Ovulation } \\
\text { rate per } \\
\text { ewe }\end{array}$} & \multicolumn{2}{|c|}{ Number (\%) of ewes conceiving } & \multicolumn{2}{|c|}{ Lambs per ewe } \\
\hline & Before $\mathrm{rbGH}$ & 3 weeks after rbGH & & First service & In total & Total & Viable $^{\mathrm{e}}$ \\
\hline NI $(n=9)$ & $73.33 \pm 1.45$ & $77.06 \pm 1.56$ & $2.22 \pm 0.22^{\mathrm{a}}$ & $8 \quad(89 \%)$ & $9(100 \%)$ & $2.22 \pm 0.22^{\mathrm{c}}$ & $2.00 \pm 0.17$ \\
\hline $\mathrm{NI}+\mathrm{rbGH}(n=10)$ & $72.72 \pm 2.58$ & $79.11 \pm 1.99$ & $2.50 \pm 0.22^{\mathrm{a}}$ & $7 \quad(70 \%)$ & $10(100 \%)$ & $2.20 \pm 0.25^{\mathrm{c}}$ & $2.00 \pm 0.21$ \\
\hline $\operatorname{IMM}(n=9)$ & $72.70 \pm 1.81$ & $73.75 \pm 1.9$ & $6.78 \pm 1.19^{b}$ & $8 \quad(80 \%)$ & $9(100 \%)$ & $4.00 \pm 0.53^{\mathrm{d}}$ & $3.13 \pm 0.61$ \\
\hline $\mathrm{IMM}+\mathrm{rbGH}(n=10)$ & $72.90 \pm 2.55$ & $74.80 \pm 2.26$ & $5.10 \pm 0.79^{b}$ & $10(100 \%)$ & $10(100 \%)$ & $4.00 \pm 0.67^{\mathrm{d}}$ & $3.11 \pm 0.51$ \\
\hline
\end{tabular}

$\mathrm{NI}$, non-immunized; $\mathrm{rbGH}$, recombinant bovine growth hormone; IMM, inhibin-immunized.

a.b Values are significantly $(P<0.001)$ different between treatment groups.

c,d Values are significantly $(P<0.05)$ different between treatment groups.

${ }^{e} P<0.02$ for combined Nl compared with combined IMM groups.

immunization cannot be due solely to increased FSH secretion as a consequence of reduced inhibin negative feedback on pituitary gonadotrophs, but might also involve a direct action of inhibin antibodies at the intraovarian level (Fray et al., 1994; Bleach et al., 1996). In view of these unexpected findings, more detailed analyses of hormone profiles in inhibin-immunized and control ewes treated with rbGH are clearly required.

Although ovarian follicle populations were not examined in the present study, an earlier study in sheep showed that inhibin immunization increased the number of follicles with diameters of 2-3 mm, 5-6 mm and $>6 \mathrm{~mm}$ (McLeod et al., 1992). Moreover, a greater proportion of these follicles was classified as oestrogen-active. Eckery et al. (1994) reported no effect of $\mathrm{rbGH}$ on the total number of antral follicles $>0.5 \mathrm{~mm}$ in diameter recovered from the ovaries of gonadotrophinstimulated ewes. A similar lack of effect on the total number of follicles > $1 \mathrm{~mm}$ in diameter was reported by Gong et al. (1996a), who administered rbGH to ewes in the absence of exogenous gonadotrophin stimulation. However, Gong et al. (1996a) noted that rbGH treatment increased the number of follicles with a diameter of $2-3 \mathrm{~mm}$ but correspondingly decreased the number of follicles with a diameter of 1-2 mm, suggesting that $\mathrm{rbGH}$ can enhance the development of follicles to the gonadotrophin-dependent stages ( $>2 \mathrm{~mm}$ in diameter) (Dufour et al., 1979; McNeilly et al., 1986). Comparable evidence of enhanced follicular recruitment in cattle treated with rbGH was reported by Gong et al. (1991, 1993). In addition, supplementary rbGH treatment in cattle receiving superovulatory treatment with pregnant mares' serum gonadotrophin or FSH has been shown to increase the ovulation rate, the total number of embryos per ova recovered and embryo quality (Gong et al., 1993, 1996b).

The tendency for $\mathrm{rbGH}$ treatment to reduce the stimulatory effect of inhibin immunization on the ovulation rate could explain the corresponding reduction in the concentration of progesterone in the luteal phase observed in the study. Alternatively, the reduction in the concentration of plasma progesterone could indicate a negative influence of raised $\mathrm{GH}$, IGF-I or both factors on progesterone synthesis. In support of this, Bryan et al. (1989) showed that treatment of gilts with pGH increased plasma and follicular fluid IGF-I concentrations but was associated with a reduction in basal and gonadotrophin-stimulated progesterone production by granulosa cells in vitro. However, Sauerwein et al. (1992) found that infusion of IGF-I during the luteal phase in cattle raised plasma concentrations of progesterone, an observation that is difficult to reconcile with the present finding and those of Bryan et al. (1989). The notion that IGF-I can modulate luteal progesterone production in ewes is supported indirectly by the recent identification of IGF receptors in sheep luteal tissue (Perks et al., 1995).

It was noted that the response of plasma IGF-I to $\mathrm{rbGH}$ administration was significantly less in inhibin-immunized ewes compared with non-immunized or PPD-immunized controls. The difference was unexpected, as was the difference in liveweight gain in the control groups compared with inhibinimmunized ewes over the 3 week period. Whether these two factors are linked is not clear, although an association between the GH response and weight gain was reported by Spicer $e$ et al. (1992), who found that prepubertal gilts from an obese genetic line showed a greater plasma IGF-I response to recombinant pig $\mathrm{GH}$ than gilts from a lean genetic line. The main response of IGF-I to systemic GH treatment will come from the liver, this organ being rich in $\mathrm{GH}$ receptors and the major site of production of IGFs and IGF-binding proteins (Giudice, 1992; Spicer and Echternkamp, 1995). The present observation suggests, therefore, that inhibin immunization alters the number or affinity of hepatic $\mathrm{GH}$ receptors, most likely through an indirect, ovary-mediated mechanism. In this regard, Breier $e$ et al. (1988a, b) showed that oestradiol can affect both the capacity of hepatic GH binding sites and circulating IGF-I concentrations in steers. This may be relevant in the case of inhibinimmunized ewes which, as shown here, have higher plasma concentrations of oestradiol than do control ewes. Recent evidence indicates that, in contrast to mouse, pig and human ovaries, IGF-I is not expressed by sheep ovarian follicles (Perks et al., 1995). This implies that any increase in intrafollicular concentrations of IGF-I in ewes receiving exogenous GH treatment would be the result of raised IGF-I concentrations in the peripheral circulation.

In conclusion, the present study found no evidence to support the hypothesis that supplementary treatment with $\mathrm{rbGH}$ can enhance the ovulatory response to inhibin immunization in ewes, and thereby improve reproductive performance. On the contrary, through mechanisms that have yet to be elucidated, rbGH treatment reduced significantly the 
stimulatory effect of inhibin immunization on plasma FSH and progesterone and tended to reduce the stimulatory effect of inhibin immunization on plasma concentrations of oestradiol and the ovulation rate.

The authors thank K. L. Edwards, S. A. Feist and D. Juniper for excellent technical assistance, F. Adriaens (Monsanto Europe SA/NV, Brussels, Begium) for providing the $\mathrm{rbGH}$ preparation (Sometribove) and S. Raiti (NIDDK, Baltimore, MD, USA) for providing IGF-I antiserum and ovine FSH assay reagents. The financial support of $\mathrm{BBSRC}$ and MAFF is gratefully acknowledged.

\section{References}

Adashi EY, Resnick CE, D'Ercole AJ, Svoboda ME and Van Wyk JJ (1985) Insulin-like growth factors as intraovarian regulators of granulosa cell growth and function Endocrine Reviews 6 400-420

Al-Obaidi SAR, Bindon BM, Findlay JK, Hillard, MA and O'Shea T (1987) Plasma follicle stimulating hormone in Merino ewes immunized against an inhibin enriched fraction from bovine follicular fluid Animal Reproduction Science 14 39-51

Baranao JLS and Hammond JM (1984) Comparative effects of insulin and insulin-like growth factors on DNA synthesis and differentiation of porcine granulosa cells Biochemical and Biophysical Research Communications 124 $484-490$

Bleach ECL, Muttukrishna S, Cunningham FJ, Knight PG and Glencross RG (1996) Effect of inhibin immunization using different synthetic peptide fragments of the bovine $\alpha_{c}$-subunit on plasma anti-inhibin titres, plasma FSH concentrations and the incidence of multiple ovulations in heifers Animal Reproduction Science 41 1-12

Breier BH, Gluckman PD and Bass JJ (1988a) The somatotrophic axis in young steers: influence of nutritional status and oestradiol-17 $\beta$ on hepatic high- and low-affinity somatotrophic binding sites Journal of Endocrinology $116169-$ 177

Breier BH, Gluckman PD and Bass JJ (1988b) Influence of nutritional status and oestradiol-17 $\beta$ on plasma growth hormone, insulin-like growth factors-I and -II and the response to exogenous growth hormone in young steers journal of Endocrinology 118 243-250

Bryan KA, Hammond JM, Canning S, Mondschein J, Carbaugh DE, Clark AM and Hagen DR (1989) Reproductive and growth responses of gilts to exogenous porcine pituitary growth hormone Journal of Animal Science 67 196-205

Davis SR, Smith JF and Gluckman PD (1990) Effects of growth hormone injections on ovulation rate in ewes Reproduction, Fertility and Development 2 173-178

Davoren JB and Hsueh AJW (1986) Growth hormone increases ovarian levels of immunoreactive somatomedin C/insulin-like growth factor- 1 in vivo. Endocrinology 118 888-890

Dufour J. Cahill LP and Mauléon P (1979) Short- and long-term effects of hypophysectomy and unilateral ovariectomy on ovarian follicular populations in sheep Journal of Reproduction and Fertility 57 301-309

Echternkamp SE, Spicer LJ, Gregory KE, Canning SF and Hammond JM (1990) Concentrations of insulin-like growth factor- 1 in blood and ovarian follicular fluid of cattle selected from twins Biology of Reproduction 43 8-14

Eckery DC, Moeller CL, Nett TM and Sawyer HR (1994) Recombinant bovine somatotropin does not improve superovulatory response in sheep journal of Animal Science 72 2425-2430

Forage RG, Brown RW, Oliver KJ, Atrache BT, Devine PL, Hudson GC, Goss NH, Bertram KC, Tolstochev P, Robertson DM, De Kretser DM, Doughton B, Burger HG and Findlay IK (1987) Immunization against an inhibin subunit produced by recombinant DNA techniques results in increased ovulation rate in sheep Journal of Endocrinology 114, R1-R4

Fray MD, Wrathall JHM and Knight PG (1994) Active immunization against inhibin promotes a recurrent increase in litter size in sheep Veterinary Record $134 \quad 19-20$

Giudice LC (1992) Insulin-like growth factors and ovarian follicular development Endocrine Reviews 13 641-669

Glencross RG, Bleach ECL, McLeod BJ, Beard AJ and Knight PG (1992) Effect of active immunization of heifers against inhibin on plasma FSH concentrations, ovarian follicular development and ovulation rate Journal of Endocrinology $13411-18$
Gong JG, Bramley T and Webb R (1991) The effect of recombinant bovine somatotrophin on ovarian function in heifers: follicular populations and peripheral hormones Biology of Reproduction $45941-949$

Gong JG, Bramley TA, Wilmut I and Webb R (1993) Effect of recombinant bovine somatotrophin on the superovulatory response to pregnant mares serum gonadotrophin in heifers Biology of Reproduction 48 1141-1149

Gong JG, Campbell BK, Bramley T and Webb R (1996a) Treatment with recombinant bovine somatotrophin enhances ovarian follicle development and increases the secretion of insulin-like growth factor-I by ovarian follicles in ewes Animal Reproduction Science 41 13-26

Gong JG, Wilmut I, Bramley TA and Webb R (1996b) Pretreatment with recombinant bovine somatotrophin enhances the superovulatory response to FSH in heifers Theriogenology 45 611-622

Henderson KM, Franchimont P, lecomte-Yerna MJ, Hudson N and Ball K (1984) Increase in ovulation rate after active immunization of sheep with inhibin partially purified from bovine follicular fluid Journal of Endocrinology $\mathbf{1 0 2}$ 305-309

Hernandez ER, Resnick CE, Svoboda ME, Van Wyk JJ, Payne DW and Adashi EY (1988) Somatomedin-C/insulin-like growth I as an enhancer of androgen biosynthesis by cultured rat ovarian cells Endocrinology 122 1603-1612

Herrler A, Einspanier R, Schams D and Niemann H (1994) Effect of recombinant bovine somatotrophin (rbbST) on follicular IGF-I contents and the ovarian response following superovulatory treatment in dairy cows: a preliminary study Theriogenology 41 601-611

Homburg R, West C, Torresani T and Jacobs HS (1990) Cotreatment with human growth hormone and gonadotrophins for induction of ovulation: a controlled clinical trial Fertility and Sterility 53 254-260

Knight PG and Castillo RJ (1988) Effects of bovine follicular fluid on gonadotrophin secretion in intact and chronically ovariectomized ewes before and after desensitization of pituitary gonadotrophs to gonadotrophin releasing hormone Journal of Endocrinology 117 341-349

Lamson G, Giudice LC and Rosenfeld RG (1991) Insulin-like growth factor binding proteins: structural and molecular relationships Growth Factors 5 $19-28$

McLeod BJ, Hunter MG, Bleach ECL, Glencross RG and Wrathall JHM (1992) Preovulatory follicle development and luteal function in ewes immunized against a synthetic peptide sequence of the a subunit of bovine inhibin journal of Endocrinology 133 413-419

McNeilly AS, Jonassen JA and Fraser HM (1986) Suppression of follicular development after chronic LHRH immunoneutralization in the ewe Journal of Reproduction and Fertility 76 481-490

Mann GE, Lamming GE and Fray MD (1995) Plasma estradiol and progesterone during early pregnancy in the cow and the effects of treatment with buserelin Animal Reproduction Science 37 121-131

Matamoros IA, Cox NM and Moore AB (1991) Effects of exogenous insulin and body condition on metabolic hormones and gonadotrophin-induced follicular development in prepubertal gilts Journal of Animal Science 69 2081-2091

Matson PL, Ibrahim ZHZ, Morris ID, Sun JG and Lieberman BA (1989) Effect of biosynthetic human growth hormone upon follicular growth in women undergoing ovarian stimulation prior to in-vitro fertilization and embryo transfer Journal of Reproduction and Fertility Abstract Series 4 Abstract 17

Mizumachi M, VogImayr JK, Washington DW, Chen C-LC and Bardin CW (1990) Superovulation of ewes immunized against the human recombinant inhibin $\alpha$ subunit associated with increased pre- and post-ovulatory follicle-stimulating hormone levels Endocrinology 126 1058-1063

Monniaux D and Pisselet C (1992) Control of proliferation and differentiation of ovine granulosa cells by insulin-like growth factor-I and follicle-stimulating hormone in vitro. Biology of Reproduction 46 109-119

Morley P, Calaresu FR, Barbe GJ and Armstrong DT (1989) Insulin enhances luteinizing hormone-stimulated steroidogenesis by porcine theca cells Biology of Reproduction $\mathbf{4 0} 735-743$

O'Shea T, Al-Obaidi SAR, Bindon BM, Cummins LJ, Findlay JK and Hillard MA (1984) Increased ovulation rate in Merino ewes and advancement of puberty in Merino lambs immunized with a preparation enriched with inhibin. In Reproduction in Sheep pp 335-386 Eds DR Lindsay and DT Pearce. Australian Academy of Sciences, Canberra

Parmer TG, Roberts CT Jr, LeRoith D, Adashi EY, Khan I, Solan N, Nelson S, Zilberstein M and Gibori G (1991) Expression, action and steroidal regulation of insulin-like growth factor-I (IGF-I) and IGF-I receptor in the rat corpus luteum: their differential role in the two cell populations forming the corpus luteum Endocrinology 129 2924-2932 
Perks CM, Denning-Kendall PA, Gilmore RS and Wathes DC (1995) Localization of messenger ribonucleic acids for insulin-like growth factor ? (IGF-I), IGF-II and the type I IGF receptor in the ovine ovary throughout the estrous cycle Endocrinology 136 5266-5273

Samaras SE, Hagen DR, Bryan KA, Mondschein JS, Canning SF and Hammond JM (1994) Effects of growth hormone and gonadotrophin on the insulin-like growth factor system in the porcine ovary Biology of Reproduction 50 178-186

Sauer MJ, Foulkes JA, Worsfold A and Morris BA (1986) Use of progesterone 11-glucuronide-alkaline phosphatase conjugate in a sensitive microtitre-plate enzyme immunoassay of progesterone in milk and its application to pregnancy testing in dairy cattle Journal of Reproduction and Fertility $\mathbf{7 6}$ $375-391$

Sauerwein H, Miyamoto A, Gunther J, Meyer HHD and Schams D (1992) Binding and action of insulin-like growth factors and insulin in bovine luteal tissue during the oestrous cycle Journal of Reproduction and Fertility 96 103-115

Savion N, Lui G, Laherty R and Gospodarowicz D (1981) Factors controlling proliferation and progesterone production by bovine granulosa cells in serum-free medium Endocrinology 109 409-420.

Schanbacher BD (1988) Increased ovulatory response of Suffolk ewes vaccinated against a synthetic fragment of porcine inhibin Biology of Reproduction 38 (Supplement 1) Abstract 40
Spicer LJ and Echternkamp SE (1995) The ovarian insulin and insulin-like growth factor system with an emphasis on domestic animals Domestic Animal Endocrinology 12 223-245

Spicer LJ, Klindt J, Buonomo FC, Maurer R, Yen JT and Echternkamp SE (1992) Effect of porcine somatotrophin on number of granulosa cell luteinizing hormone/human chorionic gonadotrophin receptors, oocyte viability, and concentrations of steroids and insulin-like growth factors I and II in follicular fluid of lean and obese gilts Journal of Animal Science 70 3149-3157

Stewart RE, Spicer LJ, Hamilton T and Keefer BE (1995) Effects of insulin-like growth factor-I and insulin on proliferation and on basal and luteinizing hormone-induced steroidogenesis of bovine thecal cells: involvement of glucose and receptors for IGF-I and LH Journal of Animal Science 73 3719-3731

Wrathall JHW, McLeod BJ, Glencross RG, Beard AJ and Knight PG (1990) Inhibin immunoneutralization by antibodies raised against synthetic peptide sequences of inhibin $\alpha$ subunit: effects on gonadotrophin concentrations and ovulation rate in sheep Journal of Endocrinology 124 167-176

Wrathall JHM, McLeod BJ, Glencross RG and Knight PG (1992) Effects of active inhibin immunization against a synthetic peptide sequence of the inhibin $\alpha$-subunit on plasma gonadotrophin concentrations, ovulation rate and lambing rate in ewes Journal of Reproduction and Fertility 95 175-182 